Portland State University

PDXScholar

$12-2021$

\title{
When a Ban Is Not a Ban: Institutional Work and the Russian Doping Scandal
}

\author{
Mathew Dowling \\ Anglia Ruskin University \\ Spencer Harris \\ University of Colorado \\ Marvin Washington \\ Portland State University, marvin6@pdx.edu
}

Follow this and additional works at: https://pdxscholar.library.pdx.edu/busadmin_fac

Part of the Sports Management Commons

Let us know how access to this document benefits you.

\section{Citation Details}

Dowling, Mathew; Harris, Spencer; and Washington, Marvin, "When a Ban Is Not a Ban: Institutional Work and the Russian Doping Scandal" (2021). Business Faculty Publications and Presentations. 247.

https://pdxscholar.library.pdx.edu/busadmin_fac/247

This Post-Print is brought to you for free and open access. It has been accepted for inclusion in Business Faculty Publications and Presentations by an authorized administrator of PDXScholar. Please contact us if we can make this document more accessible: pdxscholar@pdx.edu. 
When a Ban is Not a Ban: Institutional Work and the Russian Doping Scandal 


\begin{abstract}
There are fewer cases of such blatant acts to defy and subsequent heroic efforts to re-arrange institutional norms than the Russian Doping Scandal. In adopting a neo-institutional perspective, we theorize the scandal as a case of attempted but failed institutional disruption. More specifically, we draw upon the institutional change literature and the institutional work perspective to explain the key events surrounding and actor's response to the scandal. Our analysis utilized Gioia's methodological approach to examine secondary empirical data. Findings reveal how stakeholders circumvented traditional governance structures in an attempt to disrupt institutional arrangements, but despite this, much of the pre-existing institutional infrastructure has remained intact. We explain this outcome, in part, as a consequence of the counter-institutional work of key governing agencies and other actors to maintain the status quo within the international sport.
\end{abstract}

Keywords: Institutional theory, institutional work, doping, international sport, scandals 


\section{When a Ban is Not a Ban: Institutional Work and the Russian Doping Scandal}

There are fewer cases of such blatant and egregious acts to defy institutional norms and subsequent heroic efforts to re-arrange institutional arrangements than that of the Russian Doping Scandal (henceforth RDS). The RDS can be viewed as one of the biggest and most high-profile failures in international governance in sporting history (Harris et al., 2021; Pound, 2020). The scandal centers on institutionalized doping on an unprecedented scale involving state-sponsored, systematic attempts to dope Russian athletes in order to win medals at international competitions including the Olympic and Paralympic Games. By scandal, we specifically refer to the process through which misconduct or transgressions (e.g. systematic doping) as defined by a social control agent (e.g., anti-doping agencies) becomes public and which could potentially have negative or damaging effects on other parties (Adut, 2005). Scandals are therefore potentially transformative events, often mediated by social-control agents (Greve et al., 2010), that could lead to fundamental societal change.

The RDS case included manipulation, deceit, and cover-ups by key individuals and organizations, some of which were directly connected to international sport and domestic antidoping networks, in order to maintain the doping regime. The latter phase of the scandal also involved a deliberate attempt by Russian officials and the Russian secret service to swap dirty urine with clean samples in the lead up to and during the Sochi 2014 Winter Olympic Games in a process known as the disappearing positive methodology (IP Report 1, 2016). The RDS case reveals inherent governance failings in international sport including inept regulatory structures and poor governance practices. In some instances, these failings led to criminal offenses such as collusion, corruption, bribery, death threats, and the highly suspicious deaths of former high-level anti-doping officials. Drawing from the institutional work literature, we analyze the type of work 
done to restore the legitimacy of Russian athletes (allowing them to compete in future Olympics), and also the legitimacy of the Russian sport system. Hence the title of our paper, when a ban is not a ban insofar as we seek to explain the empirical paradox of why, despite being banned by from international competition, 282 Russian athletes were allowed to compete at the Rio 2016 Olympic Games and 335 Russian athletes were able to compete in the Tokyo 2020(+1) Olympic Games ${ }^{1}$. Thus, our institutional explanation of the RDS can help explain not only why the scandal occurred, but also the direct responses and outcomes of the scandal including why Russian athletes continue to be allowed to compete despite being banned from international competition.

The RDS case is empirically and theoretically rich as it involved multiple individuals and organizations (i.e., actors), all operating at various levels of jurisdiction, with varying degrees of power and influence. These actors include the Russian government, the state security agency FSB (Federal Security Service of the Russian Federation), national governing bodies of sport (e.g. the Russian Athletics Federation), RUSADA (the Russian Anti-Doping Agency), the World AntiDoping Agency-accredited laboratory in Moscow, international sport federations (e.g. World Athletics), as well as the International Olympic Committee (IOC), the World Anti-Doping Agency (WADA), and the Court of Arbitration in Sport (CAS), and the media. Consequently, this study incorporates the messiness of the field (Bourdieu, 1993; Washington, 2004) by bringing in multiple actors with contradictory interests to examine the RDS case. A critical aspect to the case is the fact that key individuals (e.g., whistleblowers and other anti-doping advocates) were able to circumvent traditional governing mechanisms (via the media) in order to expose the institutionalized doping regime. This study focuses on the role of these key individuals and how they were able to navigate

\footnotetext{
${ }^{1}$ Russian athletes competed nder the IOC-approved banner of the Russian Olympic Committee at Tokyo 2020(+1).
} 
their environment in an attempt to re-arrange institutional arrangements both within Russia and international sport.

The events and whistleblowing that occurred in 2014 which inter alia, led to the WADA investigations which revealed the extent of the state-sponsored doping regime were only the "tip of the iceberg" (Hermann, 2019, p. 45) of doping within international sport. Recent investigations should therefore be understood and interpreted within the broader socio-political context of postsovietism, Eastern bloc and GDR dominance of international sport throughout the 1950s to 1980s (Green \& Houlihan, 2005) and alongside claims that Russia has been systematically doping since the Cold War era, with doping a central feature of the Russian sporting system for the past 50 years (Dennis \& Grix, 2012). From an institutional perspective, the doping regime in Russia can be viewed as an enduring institution that has taken for granted social, cognitive and normative beliefs surrounding it (Scott, 1995). Seen from this perspective, the actions of whistleblowers and key anti-doping stakeholders can be understood as an attempt to disrupt an institution (i.e. the statesponsored doping regime within Russia).

In utilizing this perspective, we provide a neo-institutional explanation of how and why the scandal occurred. More specifically, we draw upon theoretical advancements within the organizational institutionalism literature, namely the institutional work perspective (Lawrence \& Suddaby, 2006; Lawrence, Suddaby, \& Leca, 2009) in addition to Seo and Creed's (2002) institutional change framework, to provide a more complex and nuanced understanding the underlying mechanisms that led to, and the consequences of, the high-profile scandal for international sport. To this end, we seek to answer the following research question: How did stakeholders attempt to disrupt and subsequently respond to institutionalized doping arrangements in Russia? 
This study contributes to the sport management literature by extending our understanding of counter-work as a potential mechanism for maintaining institutional arrangements. Previous research has examined, for example, the influence of newly created actors on existing institutional arrangements (Dowling \& Smith, 2016), how actors respond to attempts to disrupt or reconfigure institutional arrangements (Agyemang et al., 2018), navigate competing institutional pressures (Pedras et al., 2020), respond to changes and innovations (Nite \& Washington, 2017), and examine how actors are able to dominate industries through their actions (Nite, 2017; Nite \& Washington, 2017; Washington \& Ventresca, 2008). A potential shortcoming of these previous studies is that they often assume linearity with the process of 'work' being done from one actor (principal) to another (agent). In contrast, we view institutional work as a dialectical interplay between various actors, whereby work and counter-work occur simultenaously and in response to other actors in an ongoing interpretive struggle. We believe this to be a more complex and nuanced understanding of the change process (summarized in Figure 1).

Our institutional explanation of the RDS helps explain not only how and why the scandal occurred, but it also highlights the inherent resiliency of institutional arrangements in sport. That is, even despite high-profile visible attempts to disrupt institutional arrangements (e.g. whistleblowing), many institutions are able to respond to such threats through mechanisms such as counter-work in order to maintain the existing social order. Theoretically, we also think this case extends institutional theory by highlighting the "messiness" of instutional change. Often institutional change research examines a dominant protagonist and examines how a challenger fought (and won or lost) to change the dominant order. Drawing on the work of organizational fields, we suggest that institutional change is more messy and involves many actors that fight to 
change, disrupt, or stabilize the field. Finally, we also contribute to the growing work on scandals by examining how institutions work to make scandals appear as if they never happened.

We begin by providing an overview of our theoretical framework which draws upon the institutional change literature. More specifically, we integrate the institutional work perspective (Lawrence \& Suddaby, 2006; Lawrence et al., 2009) within a framework of institutional change (Seo \& Creed, 2002). In assuming no prior knowledge, we then briefly outline the research context in which our analysis focuses. Next, we outline our methodological approach including the empirical data in which our analysis is based. We then examine how stakeholders attempted to disrupt and respond to existential threats in order to disrupt and maintain existing institutional arrangements within the Russian and international Olympic sport systems. Finally, we conclude with empirical and theoretical contributions and practical implications for international sport.

\section{Conceptual Framework}

This study draws upon the scandal literature, institutional work perspective (Lawrence \& Suddaby, 2006; Lawrence, Suddaby, \& Leca, 2009), and Seo and Creed's (2002) account of institutional change to examine the events and specific practices that occurred before, during and after the initial reports concerning the RDS. In his work examining the trial of Oscar Wilde, Adut (2005) describes a scandal as a disruptive public display of some transgression. Thus, for misconduct to become scandals first, misconduct (or in his words transgressions) need to become public, and second, the publicity needs to be disruptive or jolt society (or the key stakeholders involved) into awareness of the misconduct. The primary challenge for the the stakeholders wanting to address the misconduct is to figure out how to redraw the line that has been crossed while also calculating the penality for redrawing the line (Greve et al. 2010). Furthermore, the literature demonstrates that many of these practices become normalized within organizational structures and processes in order 
to preserve the institutional order (Nite \& Nauright, 2020). The challenge for the stakeholders embroiled in the scandal is either to make the scandal go away or to minimize the penalities for committing the misconduct that led to the scandal. The work of redrawing lines, making the scandal go away, and creating and minimizing penalities all represent types of institutional work.

\section{Institutional work}

The concept of institutional work describes "the purposive action of individuals and organizations aimed at creating, maintaining and disrupting institutions" (Lawrence \& Suddaby, 2006, p. 215). In recent years, this approach has evolved into a distinct research tradition that focuses "on understanding how, why and when actors work to shape sets of institutions, the factors that affect their ability to do so, and the experience of these efforts for those involved" (Hampel et al., 2017, p. 558). In their seminal work, Lawrence and colleagues (Lawrence \& Suddaby, 2006; Lawrence

et al., 2009) outlined the institutional work perspective identifying three broad categories of institutional work: creation, maintenance and disruption. Importantly, the institutional work perspective sensitizes the reader to the fact that:

institutions shape every facet of human existence, providing meaning and motivation to our action, and holding together the material and symbolic structures that trigger and shape those action; at the same time, however, institutions are ongoing human accomplishments, constructed, and maintained by people's behavior, thoughts and feelings, often in ways that are non-reflexive and unintended, but just as often in ways that reflect people's institutional awareness, their desires to affect institutional arrangements, and the skills and resources they marshal to achieve those desires (Hampel et al., 2017, p. 559).

Institutional work, therefore, provides an analytical approach that centers on the practical actions of actors and how they are able shape institutions some of which are "highly visible and dramatic" 
whilst others are "nearly invisible and often mundane...day-to-day activities" (Lawrence et al., 2009, p. 1).

Researchers have examined various sporting contexts utilizing the institutional work perspective including governing agencies (e.g., Dowling \& Smith, 2016; Nite, 2017; Nite et al., 2019), clubs (e.g., Lok \& de Rond, 2013; Riehl et al., 2019), player unions (Cocchiarella \& Edwards, 2020), community sport organizations (Oja et al., 2019), sexual abuse (Nite \& Nauright, 2020), and mixed martial arts gyms (Helms \& Patterson, 2014; Woolf et al., 2016). Additionally, these studies have sought to understand how actors are able to influence institutional arrangements across multiple levels of analysis including the individual/micro (e.g. Lok \& de Rond, 2013), organizational (e.g. Nite, 2017; Nite et al., 2019), and field-levels (e.g. Meier \& Reinbold, 2018). These studies have mainly focused on how individual/organizational actors are able to create or maintain sport or sport-related institutions with only a few studies explicitly addressing how actors are able to disrupt institutional arrangements. This is also consistent with Nite and Edward's (2021) suggestion that sport management scholarship has not sufficiently addressed how actors engage in institutional disruption work.

One possible theoretical/empirical explanation for a lack of studies focusing on institutional disruption work is that there is little evidence of disruption occurring within sport. This explanation is also consistent with Lawrence and Suddaby's (2006) viewpoint that empirical studies of institutional disruption and deinstitutionalization are quite rare. Previous research, often pre-dating Lawrence and Suddaby's formal labelling of 'institutional work', has highlighted practices that can be viewed as disruptive (for example see Slack \& Hinings' study of Sport Canada and Washington's analysis of the National Collegiate Athletics Association). 
Another explanation for the relatively slim literature on disruption/deinstitutionalization is that (sport) researchers have traditionally been more interested in, and have therefore focused upon, explaining how sporting institutions are created, how actors have been able to maintain their permeance, or explain why certain organizations have been able to dominate particular industries (e.g. Nite, 2017; Nite \& Washington, 2017; Nite, Washington, \& Ige, 2016; Washington \& Ventresca, 2008). Perhaps yet another more practical explanation is that researchers have been unable to identify or get access to specific cases of disruption as and when they occur. In short, we think that this latter explanation is most convincing. Clearly, the sport management literature reveals "a significant gap...examining institutional disruption work, thus warranting further studies to continue the advancement of institutional theory within sport management" (Nite \& Edwards, 2021, p. 11).

\section{Institutional change}

In addition to the institutional work perspective, our analysis also draws upon Seo and Creed's (2002) conception of institutional change to explain how and why the RDS occurred and its likely consequences for international sport. Seo and Creed's (2002) account views institutional change as an outcome of dynamic interactions between institutional contradictions and human praxis. Contradictions illustrate the "ruptures and inconsistencies both among and within the established social arrangements" (p. 225), whereas praxis conveys "political action embedded in a historical system of interconnected yet incompatible institutional arrangements" (p. 223). Central to their account of institutional change is the assumption that institutions become embedded and unresponsive to their external environment, creating contradictions and tensions which accumulate over time. For Seo and Creed (2002), these contradictions and tensions "are the inevitable byproducts of the ongoing social construction of those institutions" (p. 228) and that "the 
development of social contradictions is a necessary driving force for praxis" with "human agency for institutional change [being] inseparable from institutional contradictions” (p. 231).

The institutional work perspective and Seo and Creed's institutional change framework are complementary insofar as they give prominence to the role of actors in being able to shape institutional arrangements. In addition, this literatures offers helpful insights to respond to the theoretical 'paradox of embedded agency' (i.e., how can actors who are embedded within institutional settings to think and act otherwise; Holm, 1995). Hence, we argue that Seo and Creed's institutional change framework combined with Lawrence and Suddaby's (2006) institutional work perspective offers a robust, theoretically driven, agent-centered, and practiceoriented account of institutional change that can help explain the underlying mechanisms of how and why the scandal occurred and further explicate the likely consequences for international Olympic sport. Additionally, combining these approaches enables the generation of new theoretical insights to demonstrate the messiness and complexity of the institutional change process that has not been sufficiently captured to date by either the sport management or the mainstream management literature. The next section provides a brief outline of the case before we present our methods and findings.

\section{Research Context - The Russian Doping Scandal}

The RDS represents a systemic, state-sponsored program of doping aimed at giving Russian athletes a competitive advantage against international competitors in international sport. This newer, systemic approach to doping was born out of the opportunity of the recently developed anti-doping structures, purposively initiated on the back of a poor Russian performance at Vancouver, 2010 and the need to demonstrate superiority on the home stage for Sochi, 2014. For brevity, the scandal can be seen to center on three elements. First, the Russian state and Russian 
sport systems colluded to manipulate and run the country's anti-doping structures so that these structures strategically supported doping among selected Russian athletes. This was achieved by (i) protecting doping athletes by strategically targeting certain athletes and events, while ignoring others (ii) developing bespoke drug cocktails that were highly effective but difficult to detect, and (iii) switching the samples of protected athletes so that clean rather than dirty samples were tested, as was the case at the Sochi, 2014 games. Second, the Russian Athletics Federation created a payment scheme with the International Athletics Federation (World Athletics) so that Russian athletes could pay officials to keep positive results covered up. Third, WADA, the IOC, and CAS has been seen to exhibit slow and misguided leadership in addressing the allegations of systemic doping in Russia. These governance missteps have exacerbated the scandal and extended the story of misconduct beyond Russia to the structures of international Olympic sport. A more detailed oversight of the RDS can be gleaned from the cited sources (Harris et al., 2021; IP1, 2016; IP2, 2016).

\section{Methodology}

This study is informed by a critical realistic perspective which assumes that reality exists independently and that unobservable structures cause observable events (Bhaskar, 1978). Consistent with critical realist and the neo-institutional assumptions, we argue that agents are both enabled and constrained by institutional arrangements but also are able to shape and influence these structural arrangements (Battilina, 2006).

\section{Data Sources}

We utilized secondary empirical data collected from February 2010 to June 2020 to address the first known reports of the scandal through to the most recent IOC sanctions and CAS hearings prior to Tokyo 2020(+1). Our study utilizes a range of documentation including organizational 
reports (e.g. IOC taskforce, independent commission/person reports), press releases, interview transcripts, books, and written testimony from key whistleblowers. The independent commission and independent person reports contained detailed testimonial accounts of coaches, athletes and administrators - all of which were important in understanding how actors were attempting, and continue to attempt, to shape institutional arrangements. A total of 23 documents were included in our analysis, comprising of 2577 pages. See Table 1 for a full list of data sources.

\section{$* * *$ insert table 1 (data sources) about here***}

\section{Data Analysis}

Our analysis adopted a qualitative approach that most closely aligns with the "Gioia method" (Gioia, 1994; Gioia et al., 2013). This approach is well-established within the mainstream management (Gehman et al., 2018) and sport studies literature (e.g. Fahlén \& Stenling, 2019; Nite \& Nauright, 2020; Singer et al., 2019), offering a rigorous, systematic, and inductive approach to data analysis that emphasizes the process by which actors construct and understand their lived experiences. More specifically, the Gioia method utilized here delineates themes and aggregates theoretical dimensions based on the secondary data utilizing a four-stage process: Stage 1 involved generating an initial understanding of the key events of the scandal through reading and re-reading data sources. This stage included identifying key stakeholders and producing a detailed chronological order of events (see Table 2). In stage 2, a process of data reduction and re-ordering (Strauss \& Corbin, 1990) took place to highlight shorter temporal sequences and relationships between events. Both the first and second author conducted stage 1 and 2 of the analytical process independently before agreeing the key events/timelines, aggregate first-order concepts, and second order themes. Any discrepancies were resolved through a discussion involving all three authors. We then compared and discussed the appropriateness of each criterion before proceeding to the 
next stage. Stage 3 comprised the generation of first-order codes based on the chronological events followed by a process to verify their appropriateness - see below. Stage 4 then utilized axial coding to aggregate first-order concepts to second-order themes (see middle and left side of Table 3 ). This stage also involved the deductive application Seo and Creed's (2002) framework of institutional change and Lawrence and Suddaby's institutional work framework to identify and explain particular instances of disruption and maintenance.

\section{***Table 2 (Data Structure) about here***}

\section{Research Quality}

A number of steps were taken throughout the research process in order to ensure the accuracy and trustworthiness of the data and findings. This included drawing upon multiple sources as a form of triangulation in order to identify first-order concepts and second order themes. Not only did this ensure the accuracy of the data collected, but this approach was consistent with the philosophical underpinnings of the study in that it captured the multiple realities of actors within the field. Furthermore, it was important to include both secondary sources (e.g. reports, press releases) and primary accounts (testimonials, interview transcripts), as the latter enabled us to directly understand and interpret the actions of whistleblowers who were central to the study. We also adopted a process of independent verification and confirmation of our findings throughout the latter stages of data analysis. This involved an iterative process during stages 3 and 4 where the findings were discussed with the third author, who was not directly involved in the initial data collection or early stages of the data analysis process, but had in-depth knowledge of the theoretical constructs. 


\section{Findings}

The findings below detail the ongoing work of actors attempting to disrupt or aspiring to maintain the institutional arrangements that underpin the Russian and the international Olympic sport systems. On one side, the disruptors were initially made up of key whistleblowers whose efforts were subsequently galvanized by independent athlete coalitions and a small but dynamic group of clean sport advocates. On the other side, the actors setting out to repair the disrupted institutional arrangements and maintain the status quo are represented by the Russian state, the Russian sport system and number of key agencies within the international and Olympic sport system. To begin, we demonstrate how Russian whistleblowers engaged in work aimed at addressing fairness and clean sport, and ultimately, upholding the values of Olympic sport. Following this, our analysis underlines the work of the Russian state, and the Russian sport and international Olympic sport systems aimed at demonizing the whistleblowers to defend institutional practices, re-asserting institutional powers, and re-gaining institutional leadership. These three types of work, led by Russian sport and the IOC, have exacerbated previous conflicts and triggered new responses to secure the support of athlete coalitions and clean sport advocates in order to strengthen previous work aimed at disrupting the institutional norms of international Olympic sport. A summary of our findings is presented in Table 2 .

$* * *$ Table 2 (Data Structure) about here***

\section{Calls Made by Whistleblowers to Uphold Olympic Values}

The initial allegations of serious doping violations in Russia began in February, 2010 when RUSADA employee, Vitaly Stepanov noticed concerning patterns in RUSADA's testing strategy where specific sports and athletes appeared to be offered protection from RUSADA's testing regimen. Stepanov's initial concerns were corroborated when he started dating and eventually 
married the Russian national team 800m runner, Yulia Rusonova. Over the course of their initial dating and subsequent marriage, Stepanov acquired a greater understanding of the vastness of the doping program and the key role of chief protagonists across the Russian state, Russian sport, and the Russian anti-doping apparatus. Fueled by a deep commitment to truth, a firm moral belief that clean sport is a valuable, social asset, and a strong desire to stop Russian cheating and dislocate the contradictions of the Russian anti-doping establishment, Stepanov continued to send WADA dispatches in the hope that these would trigger external intervention, undermine the normative assumptions and beliefs about the Russian anti-doping system, and ultimately drive change in these systems. Stepanov illustrated this sentiment clearly in his written testimony to the IOC's Schmid Commission:

What [we] have done is stupid if safety and security were our motivations. But safety and security are not our guiding values. We are willing to risk our safety and security because we believe in two important ideals: the value of truth and the value of clean sport... [we] would love to make athletics cleaner and we are willing to do anything to try to make a change in a better direction (Stepanov, 2017, p. 2).

While Stepanov was beginning to share insights with WADA so too were other whistleblowers. In December 2012, Darya Pischalnikova, a silver medalist Russian discus thrower at London 2012, contacted WADA to report the Russian systematic doping scheme (Ruiz, et al., 2016). Following this, in July 2013, Nick Harris and Martha Kelner, two prominent UK-based journalists, were reporting serious concerns to WADA and the IOC about the prevalence of doping in Russian sport predicated on first-hand evidence provided by Russian athletics coach, Oleg Popov (Harris, 2015). Despite the growing number of allegations, the anti-doping community did not intervene, and public awareness remained low, with the latter perhaps influencing the former. This was set 
to change as a result of key individuals using the media as a mechanism to grow public awareness of the allegations and intensify the pressure on sport to act. In this way, Jack Robertson (WADA Chief Investigations Officer) introducing the Stepanovs to Hajo Seppelt (Investigative Journalist for German broadcaster ARD), and Don Caitlin (former U.S. WADA accredited Laboratory Director) introducing Grigory Rodchenkov (Russian WADA accredited Laboratory Director) to Bryan Fogel (U.S. Documentarian) proved to be critical moves in challenging the status quo. To be clear, the high-profile coverage offered by the print/electronic media (e.g. The Mail on Sunday), mainstream television (e.g. ARD's three series documentary), and the award winning, Netflix distributed docu-film Icarus represent a new type of institutional work, acquiring external support and influence, initiated by a relatively small number of individuals, offering the potential to disrupt the institutional norms underpinning the Russian and international Olympic sport systems.

\section{Dominant Actors Demonize the Whistleblowers to Defend Institutional Practices}

The weight of media scrutiny given to the RDS was met with an onslaught of responses from Russian politicians and Russian sport officials who were committed to defend, deny and divert attention from the idea that Russia was cheating. Clearly, the Russian strategy was to develop a three-point defense. First, that the stories were a product of a U.S. led anti Russia propaganda. Second, that doping in elite sport was ubiquitous cross nations. Third, that the whistleblowers should not be trusted. Initially, Vladimir Putin strongly denied the allegations: "there never has been, nor is there now and I hope there never will be a state system of doping support in sport" (TASS, 2017, n.p.), reinforcing the idea that the entire story is a case of politics, "a foundation for building anti-Russian policy" (in Kramer, 2016, n.p.) and that all countries dope, "but we see no such politically agitated hype" when other countries dope (TASS, 2017, n.p.). Vitaly Mutko, a close Putin ally (and former Deputy Prime Minister and Former Minister of Sport) also strongly 
denied the allegations, arguing that "geopolitics had taken over common sense" (in Carroll, 2017, n.p.) and that Russia's doping problem was "no worse than any other country" (Moscow Times, 2015 n.p.). Mutko went on to discredit the Stepanovs claiming that they were motivated by "mercantile things, money or a resident permit in some country" (Tsvetkova \& Strohecker, 2015, n.p.). The whistleblowers were subject to further attacks with the spokesman of the President referring to Yulia Stepanova as "a judas" (Axon, 2016 n.p.), and Mutko attempting to belittle the whistleblowers, "who is this Stepanov, he was kicked out of here like a swindler, [now] he is for some reason interesting to the makers of some kind of films... you understand what is behind this" (AFP, 2016, n.p.). The attacks on the whistleblowers continued from Russian sport officials with Ramil Khabriev, the former Director General of RUSADA, stating that it was all politicized nonsense, the product of an "inflamed imagination" and stuff that is better suited to "spy movies" (Ellingsworth, 2016, np), and, more belligerently, Leonid Tyagachev, the Head of the Russian Olympic Committee, stating that Grigory Rodchenkov "should be shot for lying” (Walker, 2017, n.p.). To add to the insidious nature of the overall denial and cover-up, the former leaders of RUSADA, Vyacheslav Sinev, former Chairman and Nikita Kamaev, former Executive Director, who knew much about the inner workings of the doping regimen and had shared correspondence about publishing these revelations, died in suspicious circumstances, sharpening the perception about the depths to which the institution was willing to sink to maintain the status quo. In short, the evidence of Russia's response epitomizes institutional work that seeks to valorize the normative basis of the institution while, at the same time, demonizing detractors and critics.

In many respects, the institutional arrangements underpinning Russian elite sport were initially reinforced by the IOC ignoring the allegations, seemingly deferring on grounds of WADA's legitimate authority to govern on the issue, and the WADA leadership's initial 
indecision, inaction and the support that their President, Craig Reedie, showed Russian politicians and sport leaders. Indeed, we argue that these tactics, specifically the decision to ignore or delay action represents a new type of work aimed at maintaining institutional norms whereby the very foundation of the institution is reinforced as it is able to continue to exist, in its current state, in the face of new information and evidence that could potentially fundamentally disrupt the institution. Following the ARD documentary, the WADA President's personal communication with Natalya Zhelanova, Mutko's Head of Doping, exacerbated the perceived strength of the institution, illuminated the delicate nature of international sport-politics relations, and the reinforced the political and practical challenges associated with effective anti-doping governance. Reedie's email to Zhelanova made the WADA President's personal feelings clear:

On a personal level, I value the relationship I have with Minister Mutko and I shall be grateful if you will inform him that there is no intention in WADA to do anything to affect that relationship (Reedie, in Harris, 2015 - 23 August).

\section{Dominant Actors Reassert Institutional Powers}

Eventually, the weight of media scrutiny, primarily driven by the evidence presented in Hajo Seppelt's ARD documentary: The Secrets of Doping: How Russia Makes its Winner, forced WADA to create an Independent Commission. After extensive investigation by a team of investigators, led by former President and IOC doyen, Richard Pound, the IC concluded that Russia was guilty of "a systematic and centralized cover-up and manipulation of the doping control process (IP Report 1, 2016, p. 1). WADA responded to the IC report by suspending RUSADA and recommending that Russia be banned for the 2016 Rio summer Olympic Games ${ }^{2}$, thus

\footnotetext{
${ }^{2}$ At this time, WADA did not have the authority to directly impose sanctions on nations due to the scale/scope of the World Anti-Doping Code. This changed in 2017 with the introduction of the
} 
demonstrating, at least theoretically, their competence in policing and ensuring compliance with institutional norms and rules. However, this work is made all the more problematic by the way in which the IOC responded to WADA's recommendation. Here, it is important to make clear that the IOC was angered by the timing of WADA's decision and the imposition that they had been put in - to make a decision on excluding a major sporting nation, with which it has close and deep historical ties, on the eve of the world's biggest sporting competition. Consequently, the IOC decided to ignore WADA's recommendation by delegating the decision on Russia's participation in the games to each respective International Sport Federation. In many ways, this was the perfect solution to the IOC. They could demonstrate that they were policing the system, treating Russia proportionality (according to the situation and evidence in each sport), and upholding the principle of sport autonomy, examples of enabling type work that permit the IOC to reassert its power and maintain the institutional arrangements of the system.

The IOC's decision regarding Russia's participation in Rio 2016 together with the second IC report triggered the reintroduction of the whistleblowers (Rodchenkov and the Stepanovs), via key international media (e.g. CBS 60 minutes, BBC, New York Times, Sunday Times) in order to clearly state claims that the IC reports did not go far enough and the investigations did not accurately reflect the true scale of deceit in terms of the state coordination of the scheme or the range of summer and winter sports involved in it. Consequently, WADA created the Independent Person investigations, with a team of investigators led by Canadian lawyer and previous IC member, Richard McLaren. Ultimately, these investigations presented a catalog of evidence to support the conclusion that:

International Standard for Code Compliance by Signatories whereby Signatories not complying with the code (i.e. nations) could be sanctioned by WADA. 
an institutional conspiracy existed across summer and winter sports athletes who participated with Russian officials within the Ministry of Sport and its infrastructure, such as RUSADA, the Center for Sport Preparation, and the Moscow Laboratory, along with the FSB for the purposes of manipulating doping controls. The summer and winter sports athletes were not acting individually but within an organized infrastructure (IP Report 2, 2016, p. 1).

In contrast to Rio, 2016, the IP reports and the wider international media attention on the RDS, placed the IOC under pressure to act enforce sanctions on Russia. Consequently, the IOC created the Schmid (focused on systemic doping) and Oswald Commissions (focused on Sochi 2014 games) to establish the facts based on documented, independent and impartial evidence (IOC, 2017), thus enabling the IOC to further reassert its institutional power. Both DC's confirmed the IP's conclusions, that Russia was guilty of "the systemic manipulation of the anti-doping rules and the anti-doping system" (IOC, 2017, p. 28).

Interestingly, the IOC pursued a more direct, hierarchical sanction for the 2018 PyeongChang winter Games than was the case for Rio, 2016. They presented a clear public-facing commitment to the principle of natural justice and to provide a path for Russian athletes who had not been implicated in the scandal to participate in the winter games. While the IOC did implement sanctions including a ban of any Russian athlete implicated in the scandal, a ban on the flag, anthem and Russian team name and unform, a ban on Russian politicians attending the games, the Russian team maintained a strong, visible presence at the games with a team of 169 athletes under the designation Olympic Athlete from Russia. This work emphasizes the IOC's enabling capacity, on the one hand, to be seen to appropriately sanction Russia, and on the other hand, to allow 
Russian participation in the games, thereby reasserting its institutional power to preserve the normative institutional arrangements of the international Olympic sport system.

\section{Dominant Actors Regain Institutional Leadership}

There is evidence of considerable work taking place following the media attention, WADA investigations and IOC decision to ban Russia for Rio, 2016, work that is best characterized as embedding and routinizing practices to demonstrate how the IOC and WADA had regained leadership of sport and anti-doping, respectively. For example, in response to the findings of the IC/IP reports, WADA promptly revised the World Anti-Doping Code and developed the International Standard for Code Compliance by Signatories. These changes, agreed by the government and WADA's sport representatives, modified the foundational rules of sport so that WADA has the authority to sanction nations for future code violations. This change also serves the convenient purpose of freeing the IOC from direct involvement in the thorny issue of sanctioning nations for anti-doping related problems. Additionally, in 2017, the IOC created and funded the International Testing Agency (ITA) to provide additional and independent doping testing services to International Sport Federations and major sport event organizers. This innovation was clearly designed to demonstrate the IOC's commitment to improve the independent testing available to Independent Sport Federations and major sport event organizers, although the extent to which the ITA is truly independent is questionable given that it was created by the IOC, funded by the IOC and largely consists of international sport and IOC representatives. Despite these concerns, the creation of the ITA and the headline media coverage of its development was helpful work in reinforcing normative ideas about the institution, not least the IOC's commitment to the principles of fair play and clean sport. The final IOC-led initiative that can be seen to respond to and infuse institutional arrangements is the development of the new IOC athlete 365 portal. The 
portal addresses a range of issues such as integrity (clean sport, athlete safety), well-being (mental health), and the athlete voice (athletes declaration) as well as providing the commercially attractive opportunity for sponsors to be able to interact with Olympians. In sum, the IOC's Athlete 365 portal can be viewed as an institutional work designed to embed and routinize the institution insofar as it can promote an athlete-centered approach to governance while also disseminating key messages about institutional norms and expectations, and in so doing, this enables the IOC to reinforce and regain its sense of leadership of the institution.

\section{Discussion and Conclusion}

This study sought to examine how stakeholders attempted to disrupt and subsequently act to respond to institutionalized doping arrangements in Russia. In adopting a neo-institutional perspective, we theorized the scandal as a case of attempted but failed institutional disruption with clear evidence of counter-work by actors to maintain the pre-existing institutional arrangements. To be clear, our findings indicate that the RDS is neither solely a case of disruption or maintenance but rather an illustration of how, in autonomous systems such as Russian and international Olympic sport, certain types of institutional work to disrupt are almost immediately met with responses designed to maintain pre-existing arrangements. In this way, the RDS can be seen to emulate a three-part 'Dostoevsky-type' saga with antagonists and protagonists simultaneously attacking to demand change and defending to maintain institutional order (see Table 3). More importantly, we argue that the empirical evidence from the RDS offers an important theoretical contribution to the institutional change literature insofar as it reveals that in settings where actors are trying to disrupt an institutional practice, the actors that want to maintain the practice can employ a three-pronged strategy.

***insert table 3 (The Russian doping scandal as a three-part saga) about here*** 
The antagonists in the RDS were driven by their dissatisfaction and discontent with Russia - in particular, their observations of the contradictions between Russian behavior and the values of Olympic sport — rather than the more commonly asserted notion of serving and pursing their own personal interests (Lawrence \& Suddaby, 2006). In the case of the Stepanov family, one only need consider their personal sacrifice and risks to personal safety to appreciate this point more fully. Given these circumstances, and particularly the role and motives of the initial whistleblowers, we argue that Seo and Creed's (2002) conceptual framework of institutional change is instructive insofar as it emphasizes change as an outcome of the dialectical interplay between institutional contradictions and human praxis.

In contrast to normative views about institutionalism, Seo and Creed (2002) would likely take the view that Russia effectively 'sowed its own seed' of destruction through its historical association with doping in elite sport (Dennis \& Grix, 2012; Riordan, 1993). In this way, the very norms and practices of the institution, and in particular the contradictions in these institutional arrangements, were the fuel that fed the actor's discontent, clearly demonstrating the "mutually constitutive nature of structure and agency" (Seo \& Creed, 2002, p. 223). Consequently, in response to these institutional contradictions, actors utilized their agency to drive attempts to disrupt and change institutional arrangements. These contradictions are evident in the normative Russian narrative when compared to the realities of its institutional norms and practices. At a more specific level, the particular contradictions that trigger and enable praxis for institutional change start with misaligned interests. Clearly, the institutional arrangements underpinning the RDS fundamentally misaligned with the interests and needs of the whistleblowers. For Vitaly Stepanov, we argue that the misalignment between his personal work-related experiences and his personal values triggered his praxis as a dominant change agent in the RDS. In contrast, Yulia Stepanova 
and Grigory Rodchenkov, experienced a reflective shift in consciousness, driven by their personal experiences and treatment by the Russian state and sport system as 'pawns in the game' and the slow but significant realization that Russia's institutional norms and practices were no longer compatible with their career or their personal safety.

In addition to misaligned interests, the Russian institution had clearly created conditions of strong nonadaptability, where the institution is "both psychologically and economically locked in... and unresponsive to changes in their external environments" (Seo \& Creed, 2002, p. 228). The rationale for this behavior likely lay in Russia's historical commitment to pursue a 'win-atall-costs' elite sport culture to symbolically reinforce the notion of communist (over capitalist) or Russian (over Western) superiority (Arnold, 2018). However, this non-adaptability also triggered a reflective shift in the consciousness of the whistleblowers, thus enhancing their understanding of the enormity of the challenge and the need for new, creative ways of working. Thus, the work of the whistleblowers reinforces the paradox of embedded agency (Holm, 1995). Here, the whistleblowers, driven by their ongoing exposure to, and experience of, the contradictions of the Russian sport system, realize their former place as agents that maintained institutional arrangements, and recognize the need for reflective distance from the past and make the conscious choice to pursue truth in the future (Emirbayer \& Mische, 1988).

It was ultimately the institutional work of the whistleblowers, utilizing their agency in response to the contradictions in institutional arrangements, that triggered the eventual institutional crisis. However, our findings suggest that this crisis was not triggered by the initial institutional work aimed at undermining the assumptions and beliefs of the institution (Lawrence \& Suddaby, 2006), but rather as a consequence of the interplay between two new types of institutional work. Against the backdrop of continuous Russian denials and arguments that the allegations represented 
little more than U.S.-led, anti-Russian propaganda, the IOC ignored the allegations and WADA delayed intervention, unsure of how to proceed and more concerned with social media chatter and optics than discovering whether the allegations had merit (Jack Robertson, WADA Chief Investigations Officer in Epstein, 2016). We argue that this ignoring and delaying response represents a new form of institutional work insofar as it represents a purposive action, that is the act and range of work that comes with choosing to do nothing in order to avoid potential disruption and maintain current institutional arrangements. However, the decision of WADA's leadership to sit by and assess the optics was an institutional contradiction reflecting the incompatibility of WADA's actions with its foundational purpose - namely an international anti-doping agency either deliberately choosing and/or not able to respond to allegations of widespread, statesponsored, systematic doping. This incompatibility and contradiction, in turn, triggered a reflective shift in consciousness in many actors, but in particular, in Jack Robertson, WADA's Chief Investigations Officer, which lead him to introduce the Stepanov family to Hajo Seppelt, the ARD investigative journalist.

The outcome of these introductions led to a second new type of work, acquiring external support and influence-through the national and multi-national media-to expose and grow awareness of the scandal to a wider audience (e.g. the German and worldwide audience of ARD), to place increased pressure on those with responsibility to act (e.g. WADA) and consequently initiate revolutionary disruption from outside and trigger an institutional crisis. While we see overlap here with the types of work identified in Lawrence and Suddaby's (2006) original framework, we have extended our understanding of how these types of work are utilized through empirical examination. In this way, the RDS goes some way to addressing Seo and Creed's (2002) 
critical question about how marginalized or less powerful agents can mobilize the resources of other participants to support reconstruction.

\section{***insert Figure 1 process model of institutional disruption + maintenance about here***}

Ultimately, despite the contradictions, the actors' praxis including the institutional disruptive work, the case demonstrates the inherent durability and resiliency of the Russian and international Olympic sport systems, and the enduring and stable nature of institutions more generally (Powell \& DiMaggio, 1991). For international Olympic sport the resiliency is undoubtedly buttressed by Principle 5 of the IOC's Olympic Charter as it legitimizes sports right to autonomy, giving it the authority to govern its own affairs and ostensibly restricting government interference in sport. Thus, sport is able to freely govern its own affairs, including implementing changes in order to be seen to be responding to institutional crisis. Such changes can be seen, for example, in the revisions to the WADA Code, the introduction of the International Standard for Code Compliance, and the IOC's newly developed International Testing Agency. However, while these changes are important and necessary developments, we argue that they reflect operational rather than more fundamental changes to the institutional arrangements underpinning sport. Consequently, we fail to see how any of them might prevent another scandal or how they might bring about reform and a change in Russian sport. If anything, the failure to deinstitutionalize the Russian sport system ultimately reinforces the resilience of the pre-existing institutional arrangements.

In returning to Seo and Creed (2002), it is possible to conclude that whilst the whistleblowers' praxis, particularly their institutional work via the media, did initiate revolutionary change from the outside to create an institutional crisis, this crisis was not sustained to the point where it brought about institutional change. As previously mentioned, the durability 
of the institution played in key role in maintaining the status quo. However, we also believe that the actors' praxis specifically collective action, was sub-optimal. While the use of the media proved effective in garnering worldwide attention and driving WADA investigations, the pressure subsided once the regulatory agencies were perceived to be taking the issue seriously. We argue that a sustained collective action, with engagement from governments, sponsors, broadcasters and fans, would more likely have the political and financial leverage to disrupt the institution and bring about fundamental change. More broadly, we think that the reason why RDS might not have led to any type of lasting institutional change is due to the ability of the protagonists to 'do work, while not actually doing any work'. Once the media and other stakeholders thought that Russia was taking this issue seriously, they have subsequently backed off their pressure calling for change. As often happens with scandals, one way scandals go away is that they are replaced in the media with another scandal.

Our assertion that the institution did not change due to lack of sustained media pressure might be tested over the coming months. In December, 2020 CAS ruled on WADA v. RUSADA (2020/O/6689), with CAS softening the sanctions imposed on Russia on the grounds of proportionality. This decision has re-started the pendulum-like work of antagonists and protagonists. In this latest turn, the contest has moved on to a different group of antagonists (e.g. Global Athlete, AthletesCAN, German Athletes, The Athletics Association, Clean Sport Collective) and a fight over a different institutional arrangement (i.e. sanctions). This new group of actors are vocal, active on social media, and keen to challenge governments, sponsors, broadcasters and fans to demand more of international Olympic sport. Further, these actors represent a self-professed 'activist base' that can address the disconnect between sport governance and athletes, and drive change across world sport. In addition to this work, the U.S., government 
are continuing to apply pressure on WADA to change, primarily by initiating work aimed at disconnecting sanctions. This work began with the first-of-its-kind White House summit on AntiDoping, largely designed to bring high profile speakers together to denounce WADA and their ability to govern anti-doping effectively. This was followed by the US Congress passing the Rodchenkov Anti-Doping Act authorizing the U.S. to impose criminal sanctions on individuals/groups involved in international doping fraud (116 ${ }^{\text {th }}$ Congress, 2020). The passing of this Act was followed in May 2021 with the White House Office of National Drug Control Policy (ONDCP) submitting a report to the U.S. Congress focused on calls for the major reform of WADA or for the U.S. government, the largest single government contributor to WADA to continue to withhold its funding to WADA. In sum, the intervention of U.S. government marks an interesting development as national governments (excluding Russia) have been quiet, largely (self) excluded from the work of antagonists or protagonists, leaving sport to govern its own affairs in line with principle 5 of the IOC Olympic Charter ${ }^{3}$. In this way, the principle of autonomy has been a powerful device in enabling international Olympic sport to maintain the status quo. Thus, while it is likely that these developments mark the start of a new series of institutional work that will lead to changes in the dominant institution, it is unlikely that this work will lead to total disruption. Notably, in cases such as this, institutions do not actually die in the sense of being wiped off the face of the earth, they are more so reincarnated where they come back in a highly recognizable form but with slightly different actions, processes, and practices.

\footnotetext{
${ }^{3}$ Fundamental Principle 5 of the IOC's Olympic Charter states that: "Recognizing that sport occurs within the framework of society, sports organizations within the Olympic Movement shall apply political neutrality. They have the rights and obligations of autonomy, which include freely establishing and controlling the rules of sport, determining the structure and governance of their organizations, enjoying the right of elections free from any outside influence and the responsibility for ensuring that principles of good governance be applied" (IOC, 2019, p. 11).
} 
In turning to the study contributions, we add to the institutional work literature through utilizing the RDS as an empirical case to expose how actors engaged in differing types of work aimed at either disrupting or maintaining the institutional arrangements of the Russian and international Olympic sport systems. The RDS case has particular merit as empirical studies of institutional disruption and deinstitutionalization are rare (Lawrence \& Suddaby, 2006). The analysis also contributes to the little that we know about actors who defy institutional rules in the interests of particular causes or values (Agyemang et al., 2018), thereby responding to Nite and Edward's (2021) call for more research that directly examines institutional disruption work by focusing on the concerted efforts of interested actions to disrupt institutions. In addition, our work contributes to the scandal literature by examining the multiple sides of a scandal. Often it is assumed that scandals, once defined as such by a social control agent (in our case WADA, or the IOC) would lead to clear penalties that would have lasting (at least reputational) affects. By examining the many different actors involved in this case (the messiness of a field approach) we have shown how different actors work to not only reduce the penalities, but also to redefine the scandal in a way that makes it go away (back to our title of when is a ban not a ban). As our analysis of the messiness of the institutional arrangements surrounding the doping scandal reveals, there continues to be a shift in what is considered to be acceptable behavior by social control agents (namely IOC and WADA) within international sport. This shift, combined with the institutionalization of normalized practices surrounding doping, institutional rigidity and reluctance to change, and the persistent power asymmetries that continue to characterize international sport, ultimately contributed to the scandal.

Finally, our analysis reveals that that despite considerable effort by key actors both within the Russian state and international sport, it appears that much of the pre-existing institutional 
infrastructure remains intact. Consequently, we would question the extent to which any meaningful change or reform has occurred. Future research could empirically verify the nature and extent of change that has (or has not) occurred in this case. Additionally, future research could examine range of scandals confronting sport governance from an institutional work perspective, including for example sexual abuse (e.g. Nite \& Nauright, 2020), sex testing in athletics, corruption and bribery in international sport federations e.g. football/soccer, weighlitfing, volleyball, etc.), and overt governmental involvement in sport (e.g. Belarus). Further studies are also needed to examine in-detail the decision-making and experiences of the whistleblowers either through primarily or secondary accounts. We believe that understanding these micro-level processes and how embedded actors are able to navigate institutional arrangements holds particular merit for future research. 


\section{References}

Adut, A. (2005). A theory of scandal: Victorians, homosexuality, and the fall of Oscar Wilde. American Journal of Sociology, 111(1), 213-248. https://www.doi.org/10.1086/428816

AFP. (2016, June 8). Athletics: Russia shuns swindler, defector whistleblowers. AFP (Moscow). Retrieved from: https://www.thenews.com.pk/print/128212-Russia-shuns-swindler-defectorwhistleblowers

Agyemang, K., Berg, B., \& Fuller, R. (2018). Disrupting the disruptor: Perceptions as institutional maintenance work at the 1968 Olympic Games. Journal of Sport Management, 32(6), 567-580. https://doi.org/10.1123/jsm.2017-0268

Alexander, D., Hallward, L., Duncan, L.R. \& Caron, J.G. (2019). Is there still hope for clean sport? Qualitative Research in Sport, Exercise, and Health, 11(5), 618-635.

Altukhov, S. \& Nauright, J. (2018). The new sporting Cold War: implications of the Russian doping allegations for international relations and sport. Sport in Society, 21(8), 1120-1136.

Arnold, R. (2018). Sport and official nationalism in modern Russia. Problems of PostCommunism, 65(2), 129-141.

Axon, R. (2016, June 19). Russian Olympic ban bittersweet for whistleblower Vitaly Stepanov who provided doping evidence. Sydney Morning Herald. Retrieved from: https://www.smh.com.au/sport/russian-olympic-ban-bittersweet-for-whistleblower-vitalystepanov-who-provided-doping-evidence-20160619-gpmj5v.html

Battilina, J., (2006). Agency and institutions: the enabling role of individuals' social position. Organization, 13(5), 653-676. https://doi.org/10.1177/1350508406067008

Bhasker, R. (1978). The realist theory of science. Harvester Wheatsheaf. 
Bourdieu, P. (1993). The field of cultural production: Essays on art and literature. Columbia University Press.

Carrol, O. (2017, December 12). Vitaly Mutko: 2018 World Cup boss says every country is doping - but only Russia gets blamed for it. Independent. Retrieved from: https://www.independent.co.uk/news/world/europe/vitaly-mutko-russia-world-cup-2018doping-football-state-sponsor-winter-olympics-deputy-prime-minister-a8106091.html

Cocchiarella, D., \& Edwards, J. (2020). Challenging the Amateur rule in the NCAA: a case study of the failed attempt at institutional disruption by Northwestern University football players. Managing Sport and Leisure. Advanced online publication. https://www.doi.org/10.1080/23750472.2020.1820888

Cuffrey, S. (2018). Passing the baton. Brooklyn Journal of International Law, 43(2), 665-690.

Denham, B. (2019). Coverage of the Russian doping scandal. Communication in Sport, 7(3), 337-360. https://doi.org/10.1177/2167479518765188

Dennis, M., \& Grix, J. (2012). Sport under communism: behind the east german 'miracle'. Palgrave Macmillan.

Dowling, M., \& Smith, J. (2016). The institutional work of Own the Podium in developing highperformance sport in Canada. Journal of Sport Management, 30(4), 396-410.

Duval, A. (2017). The Russian doping scandal at the court of arbitration for sport: lessons for the world anti-doping system. The International Sport Law Journal, 16, 177-197. https://doi.org/10.1007/s40318-017-0107-6

Ellingsworth, J. (2016, February, 21). Russian doping official planned book before sudden death. Associated Press. Retrieved from: https://apnews.com/article/d207f87cca9f4f0bbe4f79d235bda5ca 
Emirbayer, M. \& Mische, A. (1998). What is Agency? American Journal of Sociology, 103(4), 962-1023. https://doi.org/10.1086/231294

Epstein, D. (2016). August 4. Top investigator details secret efforts to undermine Russian doping probe. ProPublica. Retrieved from: https://www.propublica.org/article/olympics-topinvestigator-secret-efforts-undermine-russian-doping-probe

Fahlén, J., \& Stenling, C. (2019). (Re)conceptualizing institutional change in sport management contexts: the unintended consequences of sport organizations' everyday organizational life. European Sport Management Quarterly, 19(2), 265-285. https://doi.org/10.1080/16184742.2018.1516795

Gehman, J., Glaser, V. L., Eisenhardt, K., Gioia, D., Langley, A., \& Corley, K. G. (2018). Finding theory-method fit: A comparison of three qualitative approaches to theory building. Journal of Management Inquiry, 27(3), 284-300. https://doi.org/10.1177/1056492617706029

Gioia, D., Thomas, J. B., Clark, S., \& Chittipeddi, K. (1994). Symbolism and strategic change in academia: The dynamics of sensemaking and influence. Organization Science, 5(3), 363383. https://doi.org/10.1287/orsc.5.3.363

Gioia, D., Corley, K. G., \& Hamilton, A. L. (2013). Seeking qualitative rigor in inductive research: Notes on the Gioia methodology. Organizational Research Methods, 16(1), 1531. https://doi.org/10.1177/1094428112452151

Greve, H. R., Palmer, D., \& Pozner, J. E. (2010). Organizations gone wild: The causes, processes, and consequences of organizational misconduct. Academy of Management annals, 4(1), 53-107. https://doi.org/10.5465/19416521003654186 
Hampel, C. E., Lawrence, T. B., \& Tracey, P. (2017). Institutional work: Taking stock and making it matter. In R. Greenwood, C. Oliver, T. B. Lawrence, \& R. E. Meyer (Eds.) The SAGE Handbook of Organizational Institutionalism (2 ${ }^{\text {nd }}$ ed., pp. 558-590). Sage.

Harris, N. (2015, August 23). WADA president Sir Craig Reedie's 'comfort' email to Russia's most senior drug-buster. Daily Mail. Retrieved from: https://www.dailymail.co.uk/sport/article-3207651/WADA-president-Sir-Craig-Reedie-scomfort-email-Russia-s-senior-drug-buster-reveals-toothless-clampdown-doping.html

Harris, S., Dowling, M., \& Houlihan, B. (2021). An analysis of governance failure and power dynamics in international sport: the Russian doping scandal. International Journal of Sport Policy and Politics, 13(3), 359-378. https://doi.org/1080/19406940.2021.1898443

Hermann, A. (2019). The tip of the iceberg: The Russian Doping Scandal Reveals a Widespread Doping Problem. Diagoras: International Academic Journal on Olympic Studies, 3, 45-71.

Holm, P. (1995). The dynamics of institutionalization: Transformation processes in Norwegian fisheries. Administrative Science Quarterly, 40(3), 398-422.

https://doi.org/10.2307/2393791

IOC. (2017). The IOC Disciplinary Commission's Report of the IOC Executive Board.

Lausanne, Switzerland: IOC.

IOC. (2019). The Olympic Charter. Lausanne, Switzerland: IOC.

IP Report 1. (2016). The Independent Person 1st Report. Professor Richard H. McLaren. IP Report 2. (2016). The Independent Person 2nd Report. Professor Richard H. McLaren. 
Kramer, A.E. (2016, June 17). Olympic ban adds to Russia's culture of grievances. The New York Times. Retrieved from: https:/www.nytimes.com/2016/06/18/world/europe/putinrussia-olympics-doping.html

Lawrence, T. B., \& Suddaby, R. (2006). Institutions and Institutional Work. In R. Clegg, C. Hardy, T Lawrence, Nord, W. (Eds.). The Sage Handbook of Organization Studies, $\left(2^{\text {nd }}\right.$ ed. pp. 215-254). Sage.

Lawrence, T. B., Suddaby, R., \& Leca, B. (Eds.). (2009). Institutional work: Actors and agency in institutional studies of organizations. Cambridge University Press.

Lok, J., \& De Rond, M. (2013). On the plasticity of institutions: Containing and restoring practice breakdowns at the Cambridge University Boat Club. Academy of Management Journal, 56(1), 185-207. https://doi.org/10.5465/amj.2010.0688

Meier, H. E., \& Reinold, M. (2018). Immunizing inefficient field frames for mitigating social problems: The institutional work behind the technocratic antidoping system. $S A G E$ Open, $8(2)$, https://doi.org/10.1177/2158244018780954

Micelotta E, Lounsbury M, \& Greenwood R. (2017). Pathways of Institutional Change: An Integrative Review and Research Agenda. Journal of Management, 43(6), 1885-1910. https://doi.org/10.1177/0149206317699522

Moscow Times. (2015). Russia says 'Sure we dope, but so does everyone else'. The Moscow Times. Retrieved from: https://www.themoscowtimes.com/2015/11/10/russia-says-surewe-dope-but-so-does-everyone-else-a50707

Nite, C. (2017). Message framing as institutional maintenance: The National Collegiate Athletic Association's institutional work of addressing legitimate threats. Sport Management Review, 20(4), 338-351. https://doi.org/10.1016/j.smr.2016.10.005 
Nite, C., \& Edwards, J. (2021). From isomorphism to institutional work: advancing institutional theory in sport management research. Sport Management Review. Advanced online publication. https://doi.org/10.1080/14413523.2021.1896845

Nite, C., \& Nauright, J. (2020). Examining institutional work that perpetuates abuse in sport organizations. Sport Management Review, 23(1), 117-129. https://doi.org/10.1016/j.smr.2019.06.002

Nite, C., \& Washington, M. (2017). Institutional adaptation to technological innovation: Lessons from the NCAA's regulation of football television broadcasts (1938-1984). Journal of Sport Management, 31(6), 575-590. https://doi.org/10.1123/jsm.2017-0159

Nite, C., Ige, A., \& Washington, M. (2019). The evolving institutional work of the National Collegiate Athletic Association to maintain dominance in a fragmented field. Sport Management Review, 22(3), 379-394. https://doi.org/10.1016/j.smr.2018.05.002

Oja, B. D., Stensland, P. J., Bass, J. R., \& Zvosec, C. C. (2019). Under the Lights: The Legitimacy, Survival, and Institutionalization of Rural Amateur Baseball. Leisure Sciences, Advanced online publication. https://doi.org/10.1080/01490400.2019.1625294

Pound, R.W. (2020). The Russian doping scandal: Some reflections on responsibility in sport governance. Journal of Olympic Studies, 1, 3-21. https://www.doi.org/10.5406/jofolympstud.1.1.0003

Powell, W., \& DiMaggio, P. (1991). The new institutionalism and organizational analysis. Chicago: University of Chicago Press.

Riehl, S., Snelgrove, R., \& Edwards, J. (2019). Mechanisms of institutional maintenance in minor hockey. Journal of Sport Management, 33(2), 93-105. https://doi.org/10.1123/jsm.2018-0041 
Riordan, J. (1993). Rewriting Soviet sport history. Journal of Sport History, 20(3), 247-258.

Ruiz, R.R., Macur, J., \& Austen, I. (2016). Even with confession of cheating, world's doping watchdog did nothing. The New York Times. Retrieved from: https://www.nytimes.com/2016/06/16/sports/olympics/world-anti-doping-agency-russiacheating.html

Scott, W. R. (1995). Institutions and organizations. Sage.

Seo, M. G., \& Creed, W. D. (2002). Institutional contradictions, praxis, and institutional change: A dialectical perspective. Academy of Management Review, 27(2), 222-247. https://doi.org/10.2307/4134353

Singer, J. N., Shaw, S., Hoeber, L., Walker, N., Agyemang, K. J., \& Rich, K. (2019). Critical conversations about qualitative research in sport management. Journal of Sport Management, 33(1), 50-63. https://doi.org/10.1123/jsm.2018-0085

Slack, T., \& Hinings, B. (1992). Understanding change in national sport organizations: An integration of theoretical perspectives. Journal of Sport Management, 6(2), 114-132. https://doi.org/10.1123/jsm.6.2.114

Stepanov, V. (2017). Written testimony of Vitaly Stepanov, submitted to the Schmid Disciplinary Commission, October 19, 2017.

Strauss, A. \& Corbin, J. (1990). Basics of qualitative research: Grounded theory procedures and techniques. Sage.

TASS. (2017, November 9). Putin links claims of Russia's alleged 'doping scheme' with upcoming elections. TASS (Russian News Agency). Retrieved from: https://tass.com/sport/974827 
Tsvetkova, M. \& Strihecker, K. (2015, November 20). Branded a traitor, Russian sports whistleblower hides abroad. Reuters. Retrieved from: https://www.reuters.com/article/usathletics-corruption-whistleblower/branded-a-traitor-russian-sports-whistleblower-hidesabroad-idUSKCN0T91PL20151120

Walker, S. (2017, November 17). Russian Olympic official says doping whistleblowers should be shot. The Guardian. Retrieved from: https://www.theguardian.com/sport/2017/nov/17/russian-olympic-official-says-dopingwhistleblower-should-be-executed

Washington, M. (2004). Field approaches to institutional change: The evolution of the National Collegiate Athletic Association 1906-1995. Organization Studies, 25(3), 393-414. https://doi.org/10.1177/0170840604040042

Washington, M., \& Ventresca, M. J. (2008). Institutional contradictions and struggles in the formation of US collegiate basketball, 1880-1938. Journal of Sport Management, 22(1), 30-49. https://doi.org/10.1123/jsm.22.1.30 
Table 1 - Key Documents and Data Sources

\begin{tabular}{|c|c|c|c|}
\hline Author & Year & Document & Pages \\
\hline Walsh, D & July 2020 & $\begin{array}{l}\text { The Russian Affair: The true story of the couple } \\
\text { who uncovered the greatest sporting scandal }\end{array}$ & 374 \\
\hline Rodchenkov, G & July 2020 & $\begin{array}{l}\text { The Rodchenkov Affair: How I brought Down } \\
\text { Putin's Secret Doping Empire }\end{array}$ & 296 \\
\hline Tygart, $\mathrm{T}$ & Feb, 2020 & Testimony to Senate Commerce Committee & 10 \\
\hline $\begin{array}{l}\text { WADA Intelligence and } \\
\text { Investigations Dept. }\end{array}$ & Nov, 2019 & $\begin{array}{l}\text { Final Report to the CRC regarding the Moscow } \\
\text { Data }\end{array}$ & 62 \\
\hline $\begin{array}{l}\text { AthletesCAN, Athletes } \\
\text { Germany, USOPCAAC, New } \\
\text { Zealand Athletes Federation, } \\
\text { Global Athlete }\end{array}$ & Oct, 2019 & Letter to Thomas Bach, IOC President & 2 \\
\hline WADA & Jul, 2019 & $\begin{array}{l}\text { Progress of the Anti-Doping System in light of } \\
\text { the Russian Doping Crisis }\end{array}$ & 41 \\
\hline IOC & Jun, 2019 & Olympic Charter (rev. 26 June, 2019) & 106 \\
\hline $\begin{array}{l}\text { Mueller, R. } \\
\text { U.S. Department of Justice }\end{array}$ & Mar, 2019 & $\begin{array}{l}\text { Report on the Investigation into Russian } \\
\text { Interference in the } 2016 \text { Presidential Election } \\
\text { (Mueller Report) }\end{array}$ & 448 \\
\hline Global Athlete & Nov, 2018 & $\begin{array}{l}\text { Statement by Global Athlete on criticism of } \\
\text { WADA by world's athletes and other anti- } \\
\text { doping reformers }\end{array}$ & 2 \\
\hline WADA & Apr, 2018 & Code Compliance by Signatories & 69 \\
\hline Schültke, A., \& Seppelt, H & Feb, 2018 & $\begin{array}{l}\text { Russia is still remaining doping country. No } \\
\text { changes at all: Interview with Grigory } \\
\text { Rodchenkov [published transcript] }\end{array}$ & 8 \\
\hline IOC Disciplinary Commission & Dec, 2017 & $\begin{array}{l}\text { IOC Disciplinary Commission's Report to the } \\
\text { IOC's Executive Board (Schmid report) }\end{array}$ & 30 \\
\hline Stepanov, V & Oct, 2017 & $\begin{array}{l}\text { Written testimony of Vitaly Stepanov } \\
\text { [submitted to IOC Schmid Disciplinary } \\
\text { Commission] }\end{array}$ & 33 \\
\hline $\begin{array}{l}\text { UNESCO Conference of Parties } \\
\text { to the International Convention } \\
\text { against Doping in Sport }\end{array}$ & Sept, 2017 & $\begin{array}{l}\text { Review of the national anti-doping policy of the } \\
\text { Russian Federation in the context of the Policy } \\
\text { Advice Project }\end{array}$ & 94 \\
\hline $\begin{array}{l}\text { U.S. House of Representatives } \\
\text { Committee on Energy and } \\
\text { Commerce }\end{array}$ & Feb, 2017 & $\begin{array}{l}\text { Ways to Improve and Strengthen the } \\
\text { International Anti-Doping System }\end{array}$ & 207 \\
\hline McLaren, $\mathrm{R}$ & Dec, 2016 & $\begin{array}{l}\text { The independent person } 2^{\text {nd }} \text { report (Mclaren/IP } \\
\text { report 2) }\end{array}$ & 151 \\
\hline WADA & Sept, 2016 & $\begin{array}{l}\text { Report of the Independent Observers - Games } \\
\text { of the XXXI Olympiad, Rio de Janeiro } 2016\end{array}$ & 55 \\
\hline Multi NADO & July, 2016 & Letter to Thomas Bach, IOC President & 5 \\
\hline IOC & July, 2016 & $\begin{array}{l}\text { IOC Statement - Russian Athletes in the } \\
\text { Olympic Games Rio } 2016\end{array}$ & 3 \\
\hline McLaren, R & July, 2016 & $\begin{array}{l}\text { The independent person report (Mclaren/IP } \\
\text { report 1) }\end{array}$ & 95 \\
\hline $\begin{array}{l}\text { WADA (Independent } \\
\text { commission) }\end{array}$ & Jan, 2016 & $\begin{array}{l}\text { The independent commission report \#2 (IC } \\
\text { report 2) }\end{array}$ & 95 \\
\hline $\begin{array}{l}\text { WADA (Independent } \\
\text { commission) }\end{array}$ & Nov, 2015 & $\begin{array}{l}\text { The independent commission report \#1: final } \\
\text { report (IC report 1) }\end{array}$ & 335 \\
\hline \multirow[t]{2}{*}{ WADA } & Nov, 2015 & Foundation Board minutes of meeting & 56 \\
\hline & & Total & 2577 \\
\hline
\end{tabular}




\section{Table 2}

Data Structure: First-order Concepts, Second-order Themes, and Aggregate Dimensions

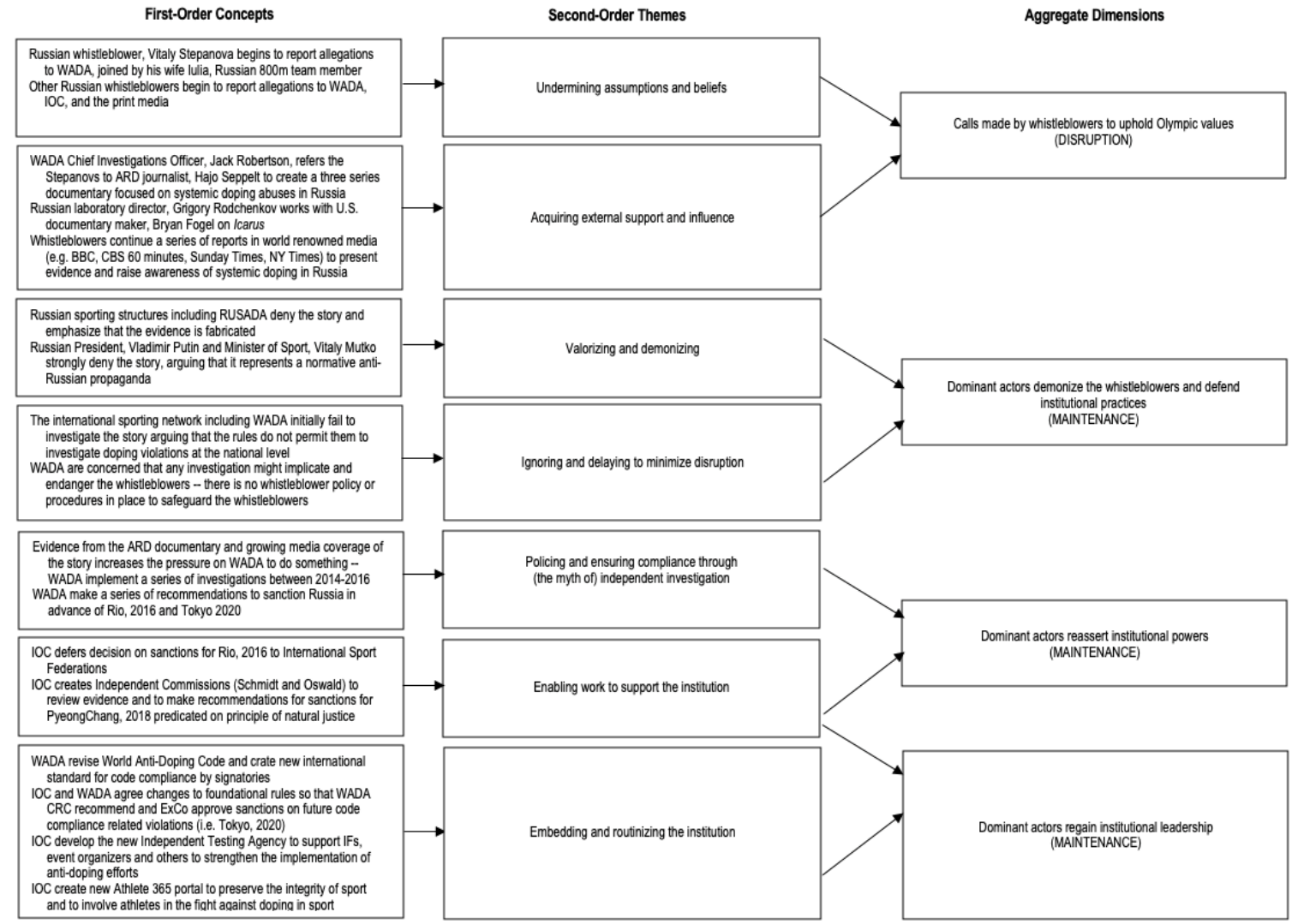




\section{Table 3}

The Russian Doping Scandal as a Three-Part Saga

\begin{tabular}{|c|c|c|}
\hline Act & Antagonists & Protagnonists \\
\hline Act 1 & $\begin{array}{l}\text { Whistle-blowers report allegations } \\
\text { Stepanov's work with ARD on } 3 \\
\text { documentaries }\end{array}$ & $\begin{array}{l}\text { Russia denies allegations } \\
\text { WADA launch investigation (IC report) } \\
\text { IOC refuse to sanction, defer decision to } \\
\text { IFs Majority of IFs (all but } 3 \text { ) do not } \\
\text { sanction Russia }\end{array}$ \\
\hline Act 2 & $\begin{array}{l}\text { Whistleblowers respond to IC report } \\
\text { and IOC deferral to IFs (New York } \\
\text { Times, CBS, BBC, Icarus, etc.) }\end{array}$ & $\begin{array}{l}\text { Russia continues to deny } \\
\text { WADA launch IP investigations, IOC } \\
\text { commissions, IOC sanction Russia as } \\
\text { bad actor (sanction, but not really } \\
\text { sanction) for PyeongChang }\end{array}$ \\
\hline Act 3 & $\begin{array}{l}\text { WADA take on/sanction Russia for } \\
\text { data manipulation - 4-year ban } \\
\text { imposed (Tokyo 2020) }\end{array}$ & $\begin{array}{l}\text { Russia denies and appeal case to CAS } \\
\text { CAS water down WADA sanctions and } \\
\text { impose similar sanction as what IOC } \\
\text { imposed in } 2018\end{array}$ \\
\hline
\end{tabular}


Figure 1: Process of disrupting and maintaining institutions

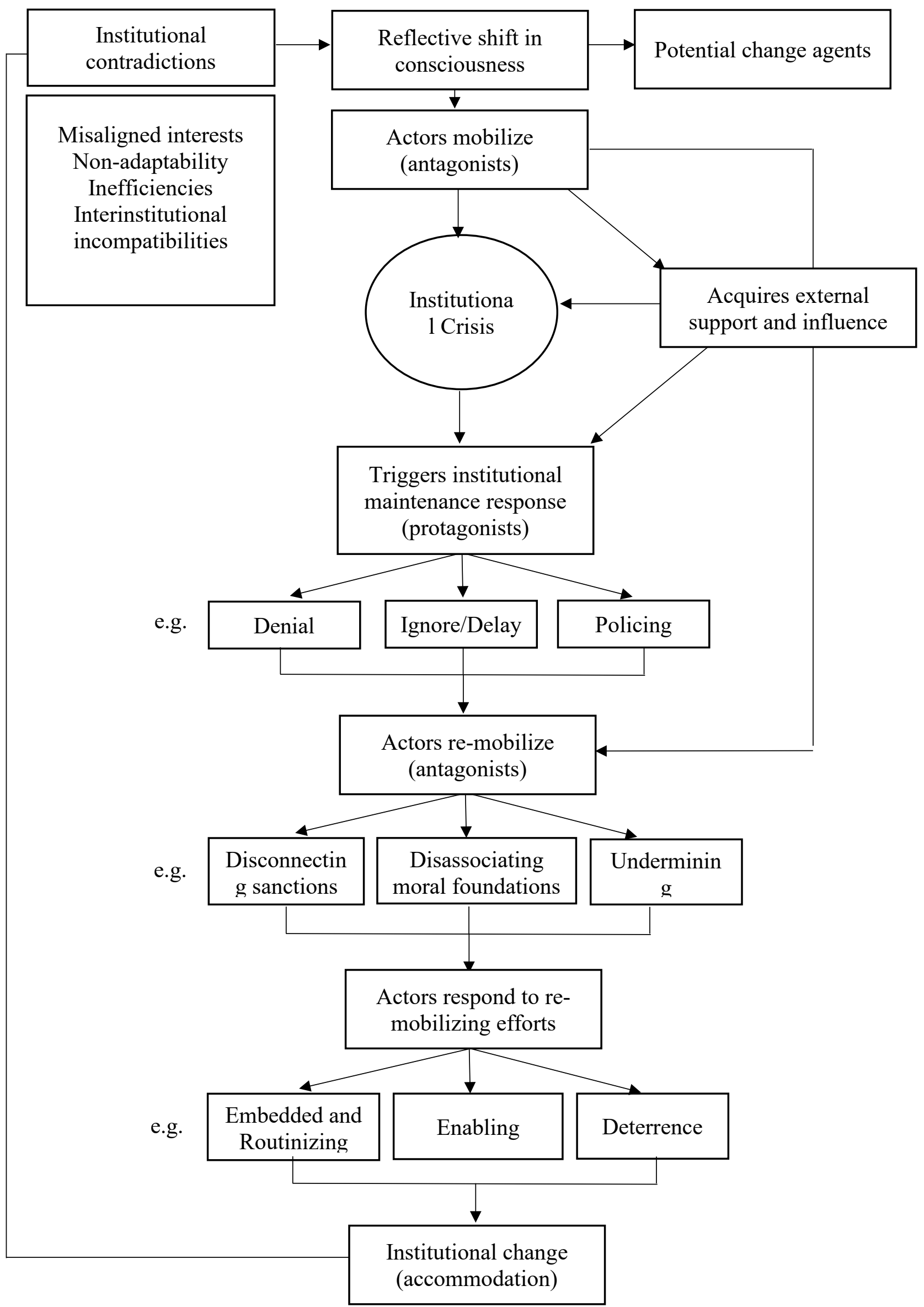

